\title{
Wastepaper Hydrolysate as Soluble Inducing Substrate for Cellulase Production in Continuous Culture of Trichoderma reesei
}

\author{
Lu-Kwang J u* and Oluwafemi A. Afolabi
}

Department of Chemical Engineering, The University of Akron, Akron, Ohio 44325-3906

\begin{abstract}
The enzymatic hydrolysate of wastepaper was evaluated for its cellulase-inducing capability and production characteristics in continuous culture of Trichoderma reese RUT C30. Under the study conditions, i.e., pH 5.0, temperature $25^{\circ} \mathrm{C}$, and typical medium C: $\mathrm{N}$ ratio, the apparent cell yield constant was found to be 0.76 ( $\mathrm{g}$ of dry cell weight/g of reducing sugar), and the maximum specific cell growth rate was $0.26 \mathrm{~h}^{-1}$. The study on the effects of medium C:N ratio confirmed an important role of $\mathrm{N}$ sources in the cellulase synthesis. The cellulase production decreased significantly when the feed concentrations of $\mathrm{N}$ sources were reduced. An experiment at $\mathrm{pH} 7.5$ with 4-fold $\mathrm{N}$ source concentrations also led to poorer cellulase production. When compared with cellulose, the wastepaper hydrolysate was found to have similar cellulase-inducing strength and to induce an apparently complete set of cellulase components. The hydrolysate was also concluded to be a better soluble inducer than sophorose. While comparable at a low dilution rate $\left(0.012 \mathrm{~h}^{-1}\right)$, the specific cellulase productivities of the hydrolysate-supported and the sophorose-induced systems exhi bited opposite trends with increasing dilution rates. The specific productivity in sophorose-induced systems decreased with an increase in the dilution rate. On the other hand, with increasing dilution rate the specific productivity in the hydrolysate-supported systems increased from $2.2 \mathrm{FPU} / \mathrm{g} \cdot \mathrm{h}$ at $\mathrm{D}=0.012 \mathrm{~h}^{-1}$ to $12.2 \mathrm{FPU} / \mathrm{g} \cdot \mathrm{h}$ at $\mathrm{D}=0.122 \mathrm{~h}^{-1}$ before beginning to decline. The initial increasing trend was attributed to the higher concentrations of inducing oligomer intermediates at larger dilution rates.
\end{abstract}

\section{Introduction}

It has been known for several decades that enzymatic hydrolysis may be used in converting cellulosic materials and wastes to useful products $(1-3)$. Its realization, however, has been hindered largely by the high production cost of the cellulase enzymes. For example, the enzyme cost has been estimated to be about $60 \%$ of the overall cost for ethanol production from cellulosic materials (4).

Most studies for cellulase production were made with batch or fed-batch fermentations of the fungi Trichoderma using solid cellulosic materials as the substrate (e.g., 5, 6). The high solid contents in these systems would burden the agitation and lower the oxygen supply efficiency of the bioreactors. This can prove critical for meeting the cells' respiration need because high cell concentrations are desirable for attaining high production rates.

The cellulase production from cellulosic materials is further affected by the complex metabolic regulation involved. Cellulase synthesis is subject to both induction and glucose repression (7). While the intermediates of cellulose hydrolysis provide effective induction (8), the concentration of the end product glucose is difficult to control. The glucose concentration is determined by the dynamic balance between the rates of glucose generation (by cellulose hydrolysis) and consumption (by microbial uptake). At low concentrations of cellulase and/or cel-

* To whom all correspondence should be addressed (phone 330-972-7252; fax 330-972-5856; E-mail Lukej u@Akron.edu).
Iulose, the glucose generation may be too slow to meet the need of active cell growth and function. On the other hand, cellulase synthesis can be halted by glucose repression when glucose generation is faster than its consumption. Expensive process control schemes, such as the slow substrate addition enabled by on-line monitoring of glucose concentration or $\mathrm{CO}_{2}$ evolution (9), are required in order to improve the productivity. The solid nature of the cellulosic materials also makes the slow, continuous delivery more difficult to achieve.

These problems can potentially be solved in a continuous culture system using sol uble substrates and inducers. The process conditions (e.g., influent substrate concentration and dilution rate) can be optimized so that a high cell concentration can be maintained at a low glucose concentration to maximize the productivity and minimize the glucose repression. Among several saccharides studied, sophorose was the most powerful soluble inducer for Trichoderma (7, 10-12). Nevertheless, besides being expensive, sophorose was still considered less potent than cellulose for cellulase induction (13). The induction by sophorose was also reported to be less complete: some components of the cellulase (exo- and some endo-glucanases) were absent in sophorose-induced systems (13).

The syrup obtained from enzymatic hydrolysis of cellulose has been shown to have cellulase-inducing ability (9). However, fundamental knowledge on its inducing and growth-supporting characteristics is lacking. The hydrolysate is readily available in the process of converting cellulosic materials to useful organic products. An integrated design to include the cellulase 


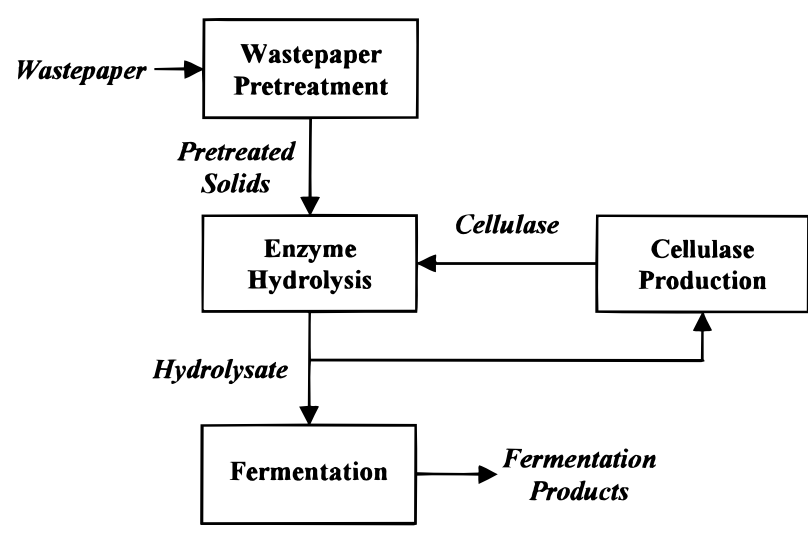

Figure 1. Flowchart showing the hydrolysate-supported celIulase production integrated in an overall process for synthesis of fermentation products from wastepaper.

production in the overall process (e.g., Figure 1) can offer significant savings in the enzyme costs, particularly those associated with enzyme recovery/purification and denaturation during processing and storage. The use of the hydrolysate as soluble inducing substrate for cellulase production in continuous culture systems deserves more study.

In this work, the ability of wastepaper hydrolysate for cellulase induction has been examined in continuous culture of Trichoderma reese RUT C30. The inducing ability of the hydrolysate has been further compared with those of cellulose, sophorose, and commercial glucose. Other characteristics of cell growth (maximum specific cell growth rate $\mu_{\mathrm{m}}$ and cell yield $\mathrm{Y}$ ) and cellulase production (volumetric and specific productivity) arealso reported.

\section{Materials and Methods}

Wastepaper Pretreatment and Hydrolysis. Newsprint was pretreated by pulping and high-temperature $\left(160^{\circ} \mathrm{C}\right.$ ) acid hydrolysis (4). A more detailed description is available elsewhere (14). The pretreated material was filtered and washed thoroughly with tap water until the $\mathrm{pH}$ reached about 5 . The analysis of the filtered material indicated a solid content of $21 \%(\mathrm{w} / \mathrm{w})$, containing $33 \%$ lignin. The rest (67\%) was assumed to be cellulose because the high-temperature acid hydrolysis was very effective in breaking the glycosidic bonds in hemicellulose and the lignin-hemicellulose bonds, resulting in nearly complete solubilization of the hemicellulose sugars (4).

Enzymatic hydrolysis of the pretreated wastepaper was carried out at $50{ }^{\circ} \mathrm{C}$ in 500-mL Erlenmeyer flasks. They were shaken at $160 \mathrm{rpm}$ for 3-4 days. The $\mathrm{pH}$ was controlled at 4.8 by using the citrate buffer. The flasks contained $10 \%(\mathrm{w} / \mathrm{v})$ solids and $10 \mathrm{~g} / \mathrm{L}$ of the enzyme Cellulase TR (Solvay Enzymes, Inc., Elkhart, IN), corresponding to 27.5 FPU (filter paper units)/g of cellulose. These conditions had been established in a previous work done in this laboratory, although the enzyme loading could be much reduced (e.g., to $2 \mathrm{~g} / \mathrm{L}$ ) if a suitable surfactant (e.g., BASF Pluronic F68) was added to enhance the hydrolysis (14). The hydrolysis product was filtered (Whatman No. 2) and the filtrate (hydrolysate) used in the later fermentation study.

Microorganism and Media. The fungus used, T. reese RUT C30 (NRRL 11460), was obtained from the United States Department of Agriculture, Agricultural Research Service Patent Culture Collection, Peoria, IL. The culture was maintained with regular subculturing on slants of Potato Dextrose Agar at $4{ }^{\circ} \mathrm{C}$. Cells from the
Table 1. Composition of Media Used in This Study

\begin{tabular}{|c|c|c|c|c|}
\hline \multicolumn{2}{|c|}{ common components } & \multicolumn{3}{|c|}{ concn } \\
\hline \multicolumn{2}{|c|}{$\begin{array}{l}\mathrm{KH}_{2} \mathrm{PO}_{4} \\
\mathrm{MgSO}_{4} \cdot 7 \mathrm{H}_{2} \mathrm{O} \\
\mathrm{CaCl}_{2} \\
\text { Tween-80 }\end{array}$} & & $\begin{array}{l}2.0 \mathrm{~g} / \mathrm{L} \\
0.3 \mathrm{~g} / \mathrm{L} \\
0.3 \mathrm{~g} / \mathrm{L} \\
0.2 \mathrm{~mL} / \mathrm{L}\end{array}$ & \\
\hline \multicolumn{2}{|c|}{$\begin{array}{l}\mathrm{FeSO}_{4} \cdot 7 \mathrm{H}_{2} \mathrm{O} \\
\mathrm{CoCl}_{2} \\
\mathrm{MnSO}_{4} \cdot \mathrm{H}_{2} \mathrm{O} \\
\mathrm{ZnSO} \cdot 7 \mathrm{H}_{2} \mathrm{O}\end{array}$} & & $\begin{array}{l}5.0 \mathrm{mg} / \mathrm{L} \\
2.0 \mathrm{mg} / \mathrm{L} \\
1.6 \mathrm{mg} / \mathrm{L} \\
1.4 \mathrm{mg} / \mathrm{L}\end{array}$ & \\
\hline & \multicolumn{4}{|c|}{ concn $(g / L)$} \\
\hline nitrogen sources & regular (C:N) & $C: 0.5 \mathrm{~N}$ & $C: 0.25 \mathrm{~N}$ & $\mathrm{C}: 4 \mathrm{~N}^{\mathrm{a}}$ \\
\hline $\begin{array}{l}\left(\mathrm{NH}_{4}\right)_{2} \mathrm{SO}_{4} \\
\text { peptone } \\
\text { urea }\left(\mathrm{NH}_{2} \mathrm{CONH}_{2}\right)\end{array}$ & $\begin{array}{l}0.280 \\
0.200 \\
0.060\end{array}$ & $\begin{array}{l}0.140 \\
0.100 \\
0.030\end{array}$ & $\begin{array}{l}0.070 \\
0.050 \\
0.015\end{array}$ & $\begin{array}{l}1.400 \\
1.000 \\
0.300\end{array}$ \\
\hline
\end{tabular}

a Feed substrate concentration, $2.5 \mathrm{~g} / \mathrm{L}$.

slants were used to inoculate a $10-\mathrm{mL}$ test tube containing a medium with $10 \mathrm{~g} / \mathrm{L}$ of glucose. The medium composition was the same as that used by Tangnu et al. (15) for $10 \mathrm{~g} / \mathrm{L}$ of cellulose, with glucose replacing cellulose. After 6 days, these cells were transferred to a stirred flask containing $50 \mathrm{~mL}$ of the same medium and incubated for 4 days. The contents of this flask served as the inoculum for the fermentation study.

The composition of the regular feed medium used in the chemostat study was also modified from that used by Tangnu et al. (15) for $10 \mathrm{~g} / \mathrm{L}$ of cellulose. However, in place of the cellulose, either reagent glucose or the enzymatic hydrolysate was used in many cases. Also, the feed reducing sugar concentration was lowered to about $2 \mathrm{~g} / \mathrm{L}$, and the concentrations of the nitrogen $(\mathrm{N})$ sources, i.e., peptone, urea, and $\left(\mathrm{NH}_{4}\right)_{2} \mathrm{SO}_{4}$, were reduced accordingly to keep the $\mathrm{C}: \mathrm{N}$ ratio constant. The feed $\mathrm{N}$ source concentrations were changed in some runs to study the effects of different $\mathrm{C}: \mathrm{N}$ ratios. The compositions of these media, excluding the source of saccharides, are summarized in Table 1. Antifoam 289 (Sigma), containing silicone and non-silicone (organic) defoamers, was added to all feed flasks in the amount of $1 \mathrm{~mL}$ per $10 \mathrm{~L}$. The antifoam was found not to contain any cellulase inducers by comparing the results obtained in the runs with and without the antifoam (results not shown).

The $\mathrm{pH}$ in this study was controlled at $5.0 \pm 0.2$ by automatic addition of $0.4 \mathrm{~N} \mathrm{HCl}$ or $\mathrm{NaOH}$. It had been found optimal for cellulase production from cellulose by Trichoderma (15). The reactor temperature was left to fluctuate with the room temperature $\left(25 \pm 3^{\circ} \mathrm{C}\right)$.

Chemostat Operation. The continuous culture was made in a 1-L Pyrex Erlenmeyer flask with an overflow glass tube connected to the side. The holding volume was $400 \pm 10 \mathrm{~mL}$ under the operation conditions. Watersaturated air was continuously pumped into the headspace above the broth. The typical aeration by submerged bubbling was not employed here to avoid the change of gas holdup with different cell and product concentrations in the highly foaming broth. Such a change would otherwise complicate the determination of dilution rate. By using a low reducing sugar concentration in the feed (i.e., $2 \mathrm{~g} / \mathrm{L}$ ), the cell concentrations in the continuous culture were kept low to ensure an adequate oxygen supply to the cells. A dissolved oxygen electrode was used to measure the dissolved oxygen concentrations in a preliminary run. They were found always higher than $50 \%$ air saturation.

The chemostat flask contained the regular medium of $2 \mathrm{~g} / \mathrm{L}$ glucose initially. It was operated at the batch mode 


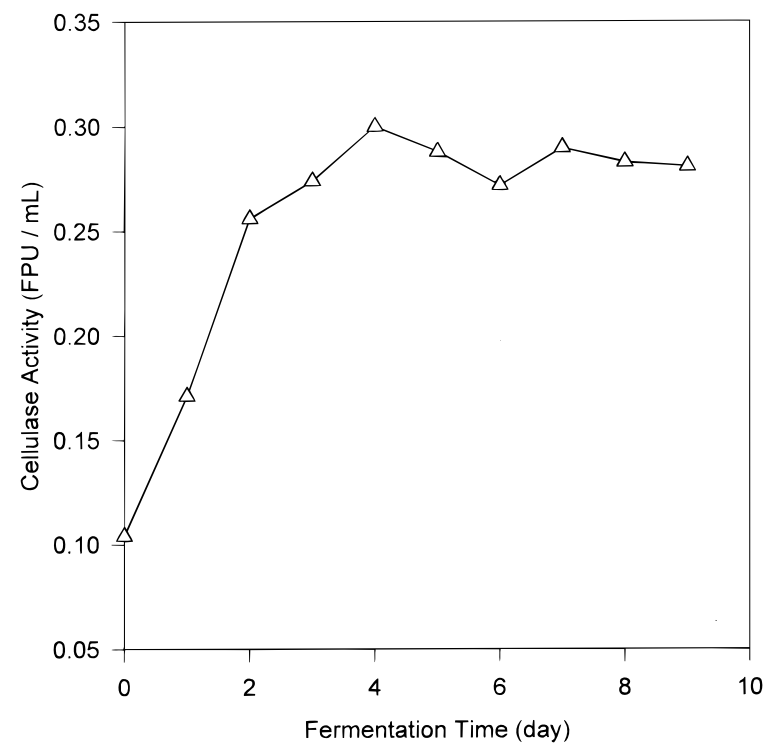

Figure 2. Profile of cellulase activity, after a change of process condition in the continuous culture, followed to indicate the establishment of a new steady state. The specific example is for a run with glucose as the sugar source plus $10 \mathrm{mg} / \mathrm{L}$ of sophorose as the inducer.

until the late exponential growth phase. The operation was then switched to continuous culture. The establishment of steady state was determined by following the cellulase activity of the system. An example is shown in Figure 2, where the cellulase activity profile was obtained in a run with glucose as the sugar source and $10 \mathrm{mg} / \mathrm{L}$ of sophorose as the inducer. After several successive steadystate data had been collected for a particular study condition, the feed composition and/or the dilution rate was changed to initiate the study for the next condition.

Analysis. Samples taken in the study were analyzed for the cell concentration, reducing sugar concentration, glucose concentration, filter paper activity, CMC-ase (or endo- $\beta$-1,4-glucanase) activity, and cellobiase (or $\beta$-glucosidase) activity. The assays for enzyme activities and reducing sugar concentration were made according to the IUPAC procedures (16). The glucose concentrations were measured using the enzymatic assay kit from Sigma Diagnostics (Procedure No. 510). Cell concentrations were determined from the optical density values measured at $600 \mathrm{~nm}$ on a spectrophotometer. A calibration curve between the optical density and the cell dry weight concentration was first developed for the determi nation.

\section{Results}

Chemostat Culture with Enzymatic Hydrolysate. Continuous culture was first made with the regular medium having the $\mathrm{C}: \mathrm{N}$ ratio used by Tangnu et al. (15). The sugar source in most runs was the filtered enzymatic hydrolysate of wastepaper. For comparison, a few runs were made using glucose, with or without sophorose as the inducer. Regardless the source, the reducing sugar concentration in the feed was kept about $2.0 \mathrm{~g} / \mathrm{L}$. It was reported that the carbon source would be limiting in media with such a C:N ratio (e.g., 15, 17). This was confirmed in batch fermentations made in this laboratory (results not shown).

The results of steady-state cell concentration (X) and reducing sugar concentration (S) are plotted against the dilution rate (D) in Figure 3. The observed profiles are typical for continuous culture (18), except that the concentration of the limiting substrate, i.e., reducing

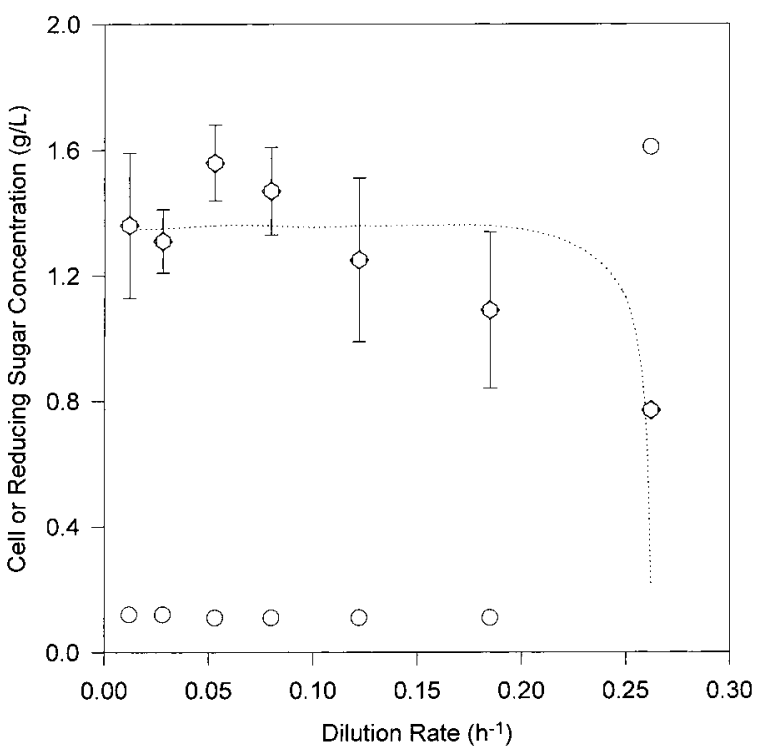

Figure 3. Steady-state cell $(O)$ and reducing sugar $(O)$ concentrations observed at varying dilution rates in the continuous culture. The wastepaper hydrolysate was used as the soluble inducing substrate, except in the system at the highest dilution rate $\left(D=0.26 \mathrm{~h}^{-1}\right)$, where glucose was the sugar source and sophorose was the inducer. The dashed curve corresponds to the best-fit equation: $X=Y\left(S_{0}-S\right)$, with $Y=0.76$.

sugar in this case, should have approached zero with diminishing dilution rate. The glucose concentration at $\mathrm{D}=0.012 \mathrm{~h}^{-1}$ was, indeed, undetectable when analyzed by the Sigma glucose assay kit. The small reducing sugar concentrations found at the low dilution rates were, therefore, from some nonmetabolizable interfering materials carried into the bioreactor with the wastepaper hydrolysate.

The apparent cell yield constant $\mathrm{Y}_{\mathrm{x} / \mathrm{s}}^{\mathrm{app}}\left(=\mathrm{X} /\left(\mathrm{S}_{0}-\mathrm{S}\right)\right.$, where $\mathrm{S}_{0}$ is the reducing sugar concentration in the feed) was found to be 0.76 . This is consistent with the literature values, i.e., 0.64 and 0.80 , that have been obtained for Trichoderma viride grown at $30{ }^{\circ} \mathrm{C}$ with glucose and ammonium as the only $\mathrm{C}$ and $\mathrm{N}$ sources (19). The value obtained in this study was closer to the larger literature value, presumably reflecting the contribution of peptone as an additional $C$ source.

The maximum specific cell growth rate $\left(\mu_{\mathrm{m}}\right)$ of T. reese RUT C30 under the studied condition was about $0.26 \mathrm{~h}^{-1}$ (Figure 3 ). The value is derived mainly from the results observed in a run with glucose as the sugar source plus $10 \mathrm{mg} / \mathrm{L}$ of sophorose as the inducer. It compares well with the value of $0.24 \mathrm{~h}^{-1}$ reported in the literature for the fungus grown on glucose (20).

The profiles of cellulase concentration (p) and volumetric and specific productivities, varying with the dilution rate, are shown in Figure 4 for the hydrolysatesupported continuous culture. The highest cellulase concentration of $0.25 \mathrm{FPU} / \mathrm{mL}$ was obtained at the lowest dilution rate of $0.012 \mathrm{~h}^{-1}$. As the dilution rate increased, the cellulase concentration declined. However, the volumetric productivity $\mathrm{Q}_{\mathrm{p}}(=\mathrm{Dp})$ and specific productivity $\mathrm{q}_{\mathrm{p}}\left(=\mathrm{Q}_{\mathrm{p}} / \mathrm{X}\right)$ both increased with increasing dilution rate up to $D=0.122 \mathrm{~h}^{-1}$. A further increment of $D$ then led to the dedine of both productivities. While the productivity profiles will be discussed in more detail later, the optimal process condition clearly involves a compromise between the productivity and the effluent cellulase concentration. A certain minimum of the latter must be met for its subsequent usage in enzymatic hydrolysis of 


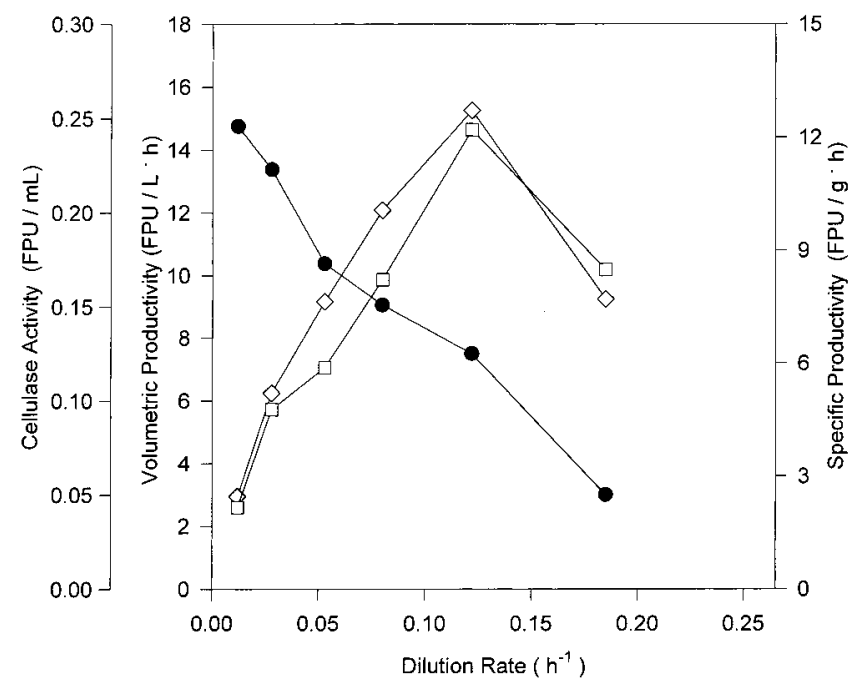

Figure 4. Profiles of cellulase activity $(\bullet)$, volumetric productivity $(\diamond)$, and specific productivity $(\square)$ observed in the wastepaper hydrolysate-supported continuous culture.

wastepaper. Otherwise, an additional concentration step would be required.

Effects of Feed C:N Ratio. Total Elimination of Nitrogen Sources. Cellulase production is generally considered to be non-growth-associated (21). To increase the productivity, it had been proposed to raise the cell concentration held in the bioreactor by cell immobilization $(22,23)$. The cells were maintained at stationary phase by omitting one or more nutrients vital for growth but presumably unessential for cellulase synthesis (23). Compared to other substrate limitations studied (e.g., $\mathrm{MgSO}_{4} \cdot 7 \mathrm{H}_{2} \mathrm{O}$ and all trace elements), the omission of $\mathrm{N}$ sources had been found to yield higher enzymetiters. The study was made in a batch mode with T. reese QM 9123, using $1 \mathrm{~g} / \mathrm{L}$ of glucose as the $C$ source and $10 \mathrm{mg} / \mathrm{L}$ of sophorose as the inducer. Only the profiles for cellulase production during a period of 7 days were presented.

In the above study, the exhaustion of $\mathrm{C}$ source must have caused cell deterioration and death during the reported period of cellulase production. This was confirmed with the measurement of cell concentration in the experiments repeated in this laboratory using a different strain, i.e., T. reese Rut C30 (results not shown). To differentiate the effects of $\mathrm{N}$ source omission from those of $\mathrm{C}$ source exhaustion, experiments were designed to include a slow, continuous feed of $C$ source. The goal was to maintain the reducing sugar level in the broth around $0.2-0.3 \mathrm{~g} / \mathrm{L}$, so that glucose repression to cellulase synthesis could also be minimized. The level was chosen on the basis of the observation in earlier batch fermentations made in this laboratory.

The cells used in this study were harvested at the late exponential growth phase, centrifuged, washed twice with distilled water, and then transferred to the media without any $\mathrm{N}$ sources. Three different systems were examined. Two of them contained initially $5 \mathrm{~g} / \mathrm{L}$ of cellulose: one as Avicel, and the other as the pretreated wastepaper (prior to the enzyme hydrolysis). A concentrated glucose solution was continuously added to maintain the reducing sugar levels in these systems, by adjusting the addition rate every 8-16 h. The third system examined contained no cellulosic solids. The initial medium had $0.8 \mathrm{~g} / \mathrm{L}$ of reducing sugars from the hydrolysate. The hydrolysate was also used for the continuous addition.

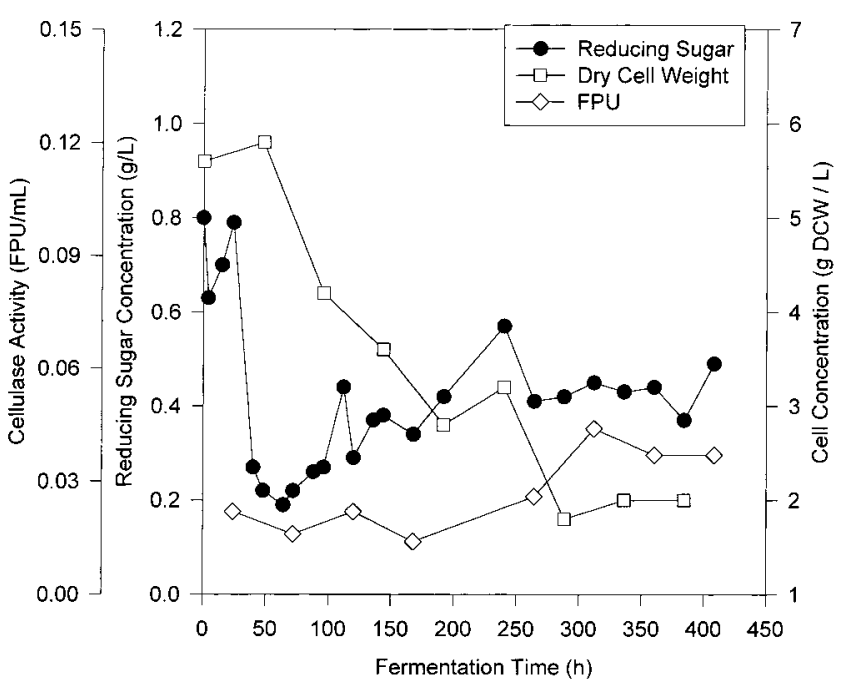

Figure 5. Results of cellulase activity, reducing sugar concentrations, and cell concentrations obtained in a run with total elimination of $\mathrm{N}$ sources. A slow, continuous feed of wastepaper hydrolysate was maintained until $136 \mathrm{~h}$. The reducing sugar concentration did not decrease afterward, indicating the rapid cell death in the $\mathrm{N}$-free system.

The results obtained in the system with wastepaper hydrolysate are shown in Figure 5. The cell concentration fell steadily from 6 to about $2 \mathrm{~g} / \mathrm{L}$, despite the slow addition of $\mathrm{C}$ source. The other two systems exhibited similar profiles. The cellulase activity did not increase much, although a higher level $(0.1 \mathrm{FPU} / \mathrm{mL})$ was reached in the Avicel-containing system after about $400 \mathrm{~h}$. Clearly, total elimination of $\mathrm{N}$ sources would not be feasible for long-term cellulase production with immobilized resting cells.

Different C:N Ratios. Experiments were further made to determine the effects of lower feed $\mathrm{N}$ source concentrations on cellulase production in continuous culture. With the ratio used by Tangnu et al. (15) being the reference $\mathrm{C}: \mathrm{N}$, the feed $\mathrm{N}$ source concentrations were decreased proportionately to make the media with $\mathrm{C}: 0.25 \mathrm{~N}$ and C:0.5N (Table 1). The dilution rate was kept constant at $0.012 \mathrm{~h}^{-1}$. The results obtained are shown in Table 2.

The steady-state cell concentration did not decrease with the decrease in the $\mathrm{N}$ source concentrations, indicating that the $\mathrm{C}$ sources were limiting even in the system of $C: 0.25 \mathrm{~N}$. The cellulase activities, however, declined as the feed $\mathrm{C}: \mathrm{N}$ ratio was decreased from that used by Tangnu et al. (15). The $\mathrm{N}$ sources thus played some positive roles in the cellulase synthesis.

A system with higher concentrations of the $\mathrm{N}$ sources, i.e., C:4N, was also examined. As shown in Table 2, a significantly higher cell concentration was obtained (beyond the increase expected from the slightly higher feed reducing sugar level, i.e., $2.5 \mathrm{~g} / \mathrm{L}$, used in this run). Peptone must have also contributed to the $C$ source for cell growth. Surprisingly, the cellulase production was much poorer than that obtained in the system of regular $\mathrm{C}: \mathrm{N}$ ratio. The $\mathrm{pH}$ in this run was not controlled by acid/ base addition. It stabilized around 7.5 at steady state. While the high $\mathrm{pH}$ has been shown to have a negative effect on cellulase production (15), it is uncertain if the excessively high $\mathrm{N}$ source concentrations al so caused the channeling of a larger portion of the $C$ source and other resources to cell growth instead of cellulase synthesis.

Comparison of Induced Cellulase Production by Hydrolysate, Sophorose, Commercial Glucose, and Cellulose. Two additional runs of continuous culture were made so that the enzymatic hydrolysate could be 
Table 2. Effects of Feed C:N Ratios on Continuous Culture with Wastepaper Hydrolysate as the Inducing Substrate

\begin{tabular}{lccccc}
\hline & $\begin{array}{c}\text { dry cell } \\
\text { weight } \\
(\mathrm{g} / \mathrm{L})\end{array}$ & $\begin{array}{c}\text { red. sugar } \\
\text { concn } \\
(\mathrm{g} / \mathrm{L})\end{array}$ & $\begin{array}{c}\text { cellulase } \\
(\mathrm{FPU} / \mathrm{mL})\end{array}$ & $\begin{array}{c}\mathrm{CMC} \text {-ase } \\
\text { (units/mL) }\end{array}$ & $\begin{array}{c}\beta \text { - } \\
\text { glucosidase } \\
\text { (units/mL) }\end{array}$ \\
\hline $1: 0.25$ & 1.81 & 0.09 & 0.133 & 2.8 & 0.02 \\
$1: 0.5$ & 1.74 & 0.1 & 0.141 & 2.9 & 0.04 \\
$1: 1$ & 1.36 & 0.12 & 0.246 & 6.8 & 0.07 \\
$1: 4^{\mathrm{a}}$ & 3.45 & 0.09 & 0.133 & na $^{\mathrm{b}}$ & na $^{\mathrm{b}}$
\end{tabular}

a Results from a run in which $\mathrm{pH}$ was not controlled but stabilized at steady state (7.47). Also, feed reducing sugar concentration was $2.5 \mathrm{~g} / \mathrm{L}$, indicating that excess peptone might have been used as carbon source. ${ }^{b} \mathrm{~N}$ ot analyzed.

compared with sophorose for their inducing capability and characteristics. Both runs were made with $\mathrm{D}=0.012$ $\mathrm{h}^{-1}$. Glucose was the reducing sugar source. One of the runs was supplemented with $10 \mathrm{mg} / \mathrm{L}$ of sophorose in the feed; the other was not. The sophor ose concentration used (i.e., $10 \mathrm{mg} / \mathrm{L}$ ) had been reported to yield the maximum induction level attainable with this disaccharide (22). The results for the specific productivities of cellulase, CMCase, and $\beta$-glucosidase obtained in these runs are summarized in Table 3. For comparison, the results from hydrolysate-supported systems at two dilution rates (0.012 and $0.122 \mathrm{~h}^{-1}$ ) are also included.

The system with only glucose also produced cellulase, although with much lower productivities than the other two systems. The residual inducing capability of commercial glucose was observed by earlier researchers (e.g., 11). It was attributed to the presence of contaminating sophor ose in the commercial glucose (11).

At $\mathrm{D}=0.012 \mathrm{~h}^{-1}$, the specific productivities for F PU, CMC-ase, and cellobiase were all comparable between the hydrolysate-supported and the sophorose-induced systems. However, the comparisons at higher dilution rates were very different. As described earlier (Figure 4), the productivity in the hydrolysate-supported systems increased with increasing dilution rate and reached the maximum at about $\mathrm{D}=0.122 \mathrm{~h}^{-1}$. The specific productivity of FPU at D $=0.122 \mathrm{~h}^{-1}$ was nearly 6-fold higher than that at $\mathrm{D}=0.012 \mathrm{~h}^{-1}$ (Table 3). On the other hand, the specific FPU productivity induced by sophorose was reported to decrease when the dilution rate was increased from 0.012 to $0.05 \mathrm{~h}^{-1}$ (17). The different productivity trends between the two systems are discussed in more detail later. Nonetheless, the enzymatic hydrolysate is shown clearly to be a better soluble inducing substrate than the sophorose-supplemented glucose solution.

A study with $T$. reese QM 9123 showed that the induction by sophorose $(250 \mathrm{mg} / \mathrm{L})$ produced a less complete set of cellulase (13). Certain components of cellulase (exo- and some endo-glucanases) were absent when compared (using electrophoresis) with the enzymes induced by cellulose. The ratio of CMC-ase activity over FPU was 40 for the sophorose-induced system, while that for the cellulose-supported system was 26 (13). In the current study, the ratios obtained at $D=0.012 \mathrm{~h}^{-1}$ for the hydrolysate-supported and sophorose-induced systems were similar: 28 for the former and 27 the latter (Table 3). At higher dilution rates in the hydrolysatesupported systems, the ratios were slightly lower, e.g., 24 for $D=0.122 \mathrm{~h}^{-1}$. It should be pointed out that these ratios were comparable to the value of 26 obtained for the cellulose-induced systems in Sternberg and Mandels's study (13). The large ratio of 40 obtained with sophorose in their study might have resulted from the low $\mathrm{pH}$ value (i.e., 2.8) used. The low $\mathrm{pH}$ was found optimal for the
Table 3. Comparison of Cellulase Induction

\begin{tabular}{|c|c|c|c|c|}
\hline \multirow[b]{2}{*}{$\begin{array}{l}\text { C source/ } \\
\text { inducer }\end{array}$} & \multirow[b]{2}{*}{ system } & \multicolumn{3}{|c|}{$\begin{array}{l}\text { specific productivity } \\
\text { (units/g·h) }\end{array}$} \\
\hline & & FPU & $\begin{array}{l}\text { CMC- } \\
\text { ase }\end{array}$ & $\begin{array}{c}\beta- \\
\text { glucosidase }\end{array}$ \\
\hline glucose & & 0.46 & 8.8 & 0.08 \\
\hline $\begin{array}{l}\text { glucose + } \\
\text { sophorose } \\
(10 \mathrm{mg} / \mathrm{L})\end{array}$ & $\begin{array}{l}\text { continuous, } \\
\qquad D=0.012 \mathrm{~h}^{-1}\end{array}$ & 2.24 & 60.0 & 0.65 \\
\hline hydrolysate & & 2.17 & 60.0 & 0.61 \\
\hline hydrolysate & $\begin{array}{l}\text { continuous, } \\
\qquad \mathrm{D}=0.122 \mathrm{~h}^{-1}\end{array}$ & 12.20 & 293.0 & 1.95 \\
\hline cellulose & fed-batch & $1.37-4.20$ & nac & nac \\
\hline cellulose ${ }^{b}$ & batch & 7.40 & nac & nac \\
\hline
\end{tabular}

a Strain, T. reese Rut C30; volume, $10.5 \mathrm{~L}$; cellulose, $\alpha$ Floc ( $J$ ames River Corp.). The values of specific FPU productivity are for the runs with different fed-batch strategies (6). b Strain, $T$. reesei QM 9414; volume, 300 L; cellulose, spruce sulfite pulp (24). c Not available.

production of CMC-ase (13) but not for FPU (10). Of course, the difference in the strains of $\mathrm{T}$. reese employed (i.e., RUT C30 versus QM 9123) might also be a factor. Nonetheless, the results of this study suggest that a complete induction for cellulase synthesis is achievable by wastepaper hydrolysate.

The cellulase-inducing capability of the hydrolysate can be further compared with that of the cellulose reported in the literature. Continuous culture with cellulose was not easy to manage at low dilution rates, especially on a small laboratory scale, because the cellulose sol ids tended to settle and clog the feed line. The results of some batch and fed-batch fermentations reported in the literature $(6,24)$ have been used to evaluate the specific cellulase productivity in cellulose-supported systems. The values are summarized in Table 3. These values are assessed only for the period of active cellulase production, to minimize the effects of other inhibition, repression, and limitation. The computation was based on the following equation:

$$
\mathrm{q}_{\mathrm{p}}=\frac{\Delta \mathrm{p}}{\Delta \mathrm{t} \bar{X}}
$$

where $\Delta p$ is the produced enzyme activity during the period of active cellulase synthesis $(\Delta t)$. The timeaveraged cell concentration $(\bar{X})$ is determined by numerical integration using the trapezoid rule (25).

The estimated values of $\mathrm{q}_{p}$ in the cellulose-induced systems (i.e., 1.4-7.4 F PU/g.h) were in the range (i.e. 2.2-12.2 FPU/g.h) obtained in the hydrolysate-supported continuous culture at varying dilution rates. The hydrolysate was therefore shown to have cellulase-inducing capability comparable with that of cellulose. The values obtained in the batch and fed-batch systems were suboptimal because they represented the averaged productivity over the changing metabolic stage. In some cases, they were also affected by glucose repression during the periods of higher glucose levels.

\section{Discussion}

Varying with the dilution rate, a unique trend of specific cellulase productivity has been observed in this study for the hydrolysate-supported systems. This is shown in Figure 6, together with the profile reported in the literature for a system using commercial glucose (Cerelose) as the C source (17). This source of glucose was known to contain small quantities of sophorose that 


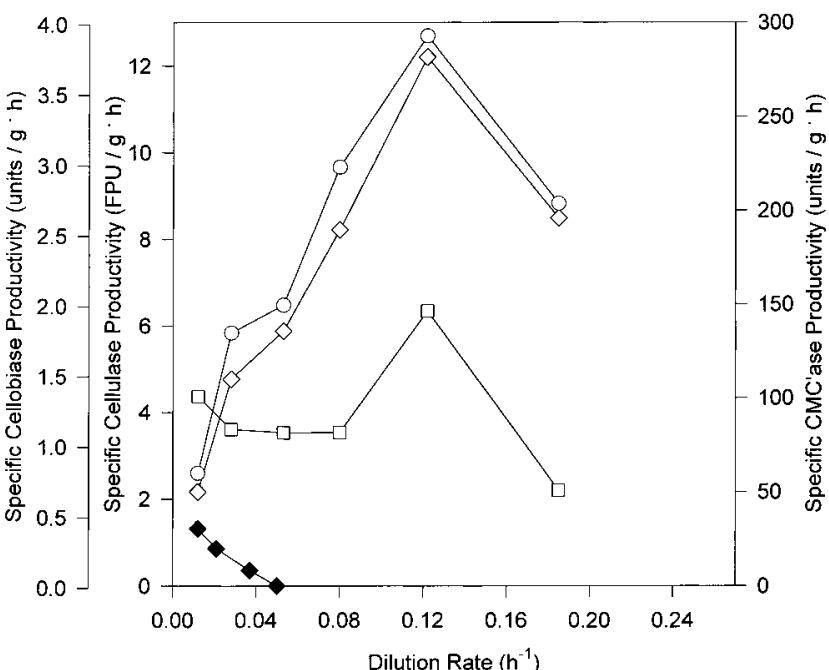

Figure 6. Profiles for specific productivity of cellulase (FPU, $\diamond), C M C$-ase $(O)$, and cellobiase $(\square)$ observed in the wastepaper hydrolysate-supported continuous culture as well as that for specific cellulase productivity in sophorose-induced systems ( $\bullet$ reported in the literature (17).

provided the induction for the observed cellulase synthesis (17). The trends of FPU productivity observed in these two studies were clearly opposite at low dilution rates, although a much wider range of dilution rate was covered in the current study.

Thetrend of decreasing specific FPU productivity with increasing dilution rate in the sophorose-induced system is first discussed. Although slowly metabolized if present as the sole sugar source, sophorose is generally considered as a gratuitous inducer for cellulase synthesis by T. reese when glucose is present (13). The inducer concentrations in the sophorose-induced systems would be practically constant at various dilution rates: all were equal to the feed sophorose concentration. The variation of specific productivity could not be attributed to the different inducer concentrations. Brown and Zainudeen (17) explained the phenomenon by a required maturation of the cells for cellulase synthesis. The lower specific productivity at a higher dilution rate reflected the larger fraction of "immature" cells in the system. Webb et al. (22) observed a similar behavior of cellulase productivity in their systems using immobilized cells. They, however, suggested the glucose limitation at the low growth rates being responsible for the increased productivity. Similar phenomena of apparent negative dependency on cell growth were observed for production of many other secondary metabolites (e.g., 26, 27). Some were successfully explained by catabolite repression and/or induction by the accumulated intermediates during slower growth (26). However, the responsible mechanism for the decreased cellulase synthesis by $\mathrm{T}$. reese at higher dilution rates is still uncertain.

On the other hand, the initial increasing trend of FPU productivity observed in the hydrolysate-supported systems may be attributed to the higher concentrations of inducers present at larger dilution rates. The intermediate oligomers produced during the process of cellulose hydrolysis are the natural inducers for cellulase (28). Sophorose is also found to be present in the cellulose hydrolysate (8). It is believed to be formed by the transferase action of $\beta$-glucosidase, which is capable of forming $\beta$-linked disaccharides (including sophorose) in the presence of glucose and cellobiose (13). Other than sophorose, the oligomer inducers are short-living intermediates. Their steady-state concentrations in the biore actor are expected to vary with the dilution rate. With increasing dilution rates, the residence times are shorter and the concentrations of hydrolyzing enzymes (cellulase) lower (as shown in Figure 4). Both favor a lower conversion of the oligomers in the bioreactor. Consequently, the inducer concentrations should increase with increasing dilution rates.

At the low dilution rate range $\left(0.012-0.122 \mathrm{~h}^{-1}\right)$, the positive effects of the higher inducer concentrations appeared to overcome the negative dependency described above for the sophorose-induced systems. This led to the increase in cellulase productivity with increasing dilution rates. The eventual decline of the productivity at much higher dilution rates $\left(>0.122 \mathrm{~h}^{-1}\right)$ could result from (1) the approach of maximum induction level, so that a further increase in the inducers' concentrations had a diminishing marginal effect, and/or (2) the stronger negative dependency, especially glucose repression, at these high dilution rates.

The mechanism proposed above can also be used to explain the trends for CMC-ase and cellobiase observed in this study (Figure 6). The similar increasethendecrease trend found for the CMC-ase production is anticipated because the induction of CMC-ase also relies strongly on the intermediate oligomer inducers. On the other hand, sophorose is responsible for a main portion of the cellobiase induction (10). This would be especially true at small dilution rates when other inducing oligomers were present at much lower concentrations. The relatively constant cellobiase productivity observed initially $\left(\mathrm{D} \leq 0.08 \mathrm{~h}^{-1}\right.$ ) reflects the balance between the aforementioned negative dependency and the increasing trend caused by the increasing concentrations of other intermediate inducers for cellobiase. The latter appeared stronger at higher dilution rates $\left(0.08 \mathrm{~h}^{-1} \leq \mathrm{D} \leq 0.122\right.$ $\mathrm{h}^{-1}$ ), as suggested by the increased cell obiase productivity (Figure 6). Eventually, the decline trend set in at even higher dilution rates $\left(\mathrm{D} \geq 0.122 \mathrm{~h}^{-1}\right)$, just as that observed for the productivity of PFU and CMC-ase.

The use of enzymatic hydrolysate for cellulase production is economically significant, especially when integrated in the overall process of cellulosic biomass conversion. However, the induction and production characteristics of the hydrolysate-supported systems are complex, as shown in this work. A future study is warranted to provide clearer understanding and to develop a more quantitative kinetic description of the systems.

\section{Conclusions}

The enzymatic hydrolysate of wastepaper was used as the soluble inducing substrate for cellulase production in continuous culture of Trichoderma reese RUT C30. The $\mathrm{pH}$ was controlled at $5.0 \pm 0.2$ and temperature at $25 \pm 3{ }^{\circ} \mathrm{C}$. With the medium C:N ratio used by Tangnu et al. (15), the apparent cell yield constant was found to be 0.76 ( $g$ of dry cell weight/g of reducing sugar) and the maximum specific cell growth rate $0.26 \mathrm{~h}^{-1}$.

The study on the feasibility of cellulase production by resting cells indicated that this could not be accomplished by total elimination of $\mathrm{N}$ sources from the medium because rapid cell deterioration and death would occur. The study on the effects of medium $\mathrm{C}: \mathrm{N}$ ratio further confirmed an important role of $\mathrm{N}$ sources in the cellulase synthesis: cellulase production was found to decrease significantly when the feed concentrations of $\mathrm{N}$ sources were reduced from that used by Tangnu et al. (15). An experiment at $\mathrm{pH} 7.5$ with 4-fold $\mathrm{N}$ source concentrations al so led to poorer cellulase production, although the cell 
concentration was much higher due to the contribution of peptone as $C$ source.

The hydrolysate was a much better soluble inducer than sophorose. While they showed comparable specific cellulase productivities at a low dilution rate $\left(0.012 \mathrm{~h}^{-1}\right)$, their performance with increasing dilution rates exhibited opposite trends. The specific productivity in sophoroseinduced systems was reported in the literature to decrease with an increase in the dilution rate. On the other hand, the specific FPU productivity in the hydrolysatesupported systems increased initially with the dilution rate. A 6-fold higher maximum productivity was reached at $\mathrm{D}=0.122 \mathrm{~h}^{-1}$ before it began to decline. A similar trend was observed for the CMC-ase productivity. The cellobiase productivity was, however, relatively constant at low dilution rates, increasing at the middle range, and decreasing eventually as the productivity of FPU and CMC-ase. The phenomena may be explained by the change of inducer concentrations with the dilution rate in the hydrolysate-supported systems.

When compared with cellulose, the wastepaper hydrolysate was found to have similar cellulase-inducing strength and to induce an apparently complete set of cellulase components.

\section{Acknowledgment}

We thank Dr. J ohn A. Glass of the EPIC (Edison Polymer Innovation Corp.) Mini Pilot Polymerization Plant for his help with the pulping and acid pretreatment of the newsprint. This work was partly supported by REnewed energy (Warrensville Heights, $\mathrm{OH}$ ).

\section{References and Notes}

(1) Batt, C. A. Biomass. In Biotechnology: The Scienceand the Business; Moses, V., Cape, R. E., Eds.; Harwood Academic: New York, 1991; pp 521-536.

(2) Blanch, H. W.; Wilke, C. R. Cellulase Production and Kinetics. In Proceedings-I nternational Symposium on Ethanol from Biomass (Winnipeg, 1982); Duckworth, H. E., Thompson, E. A., Eds.; Royal Society of Canada: Ottawa, Canada, 1983; pp 415-446.

(3) Reese, E. T. History of the Cellulase Program at the U. S. Army Natick Development Center. Biotechnol. Bioeng. Symp. 1976, 6, 9-20.

(4) Torget, R.; Himmel, M.; Grohmann, K.; Wright, J . D. Initial Design of a Dilute Sulfuric Acid Pretreatment Process for Aspen Wood Chips. Appl. Biochem. Bi otechnol . 1988, 17, 89 104.

(5) Esterbauer, H.; Steiner, W.; Labudova, I.; Hermann, A.; Hayn, M. Production of Trichoderma Cellulase in L aboratory and Pilot Scale. Bioresour. Biotechnol. 1991, 36, 51-65.

(6) Mclean, D. D.; Abear, K.; Podrunzy, M. F. Fed-batch Production of Cellulases Using Trichoderma reesei Rutgers C-30. Can. J . Chem. Eng. 1986, 64, 588-596.

(7) Sternberg, D.; Mandels, G. R. $\beta$-Glucosidase I nduction and Repression in the Cellulolytic Fungus Trichoderma reesei. Exp. Mycol. 1982, 6, 115-124.

(8) Allen, A. L.; Roche, C. D. Effects of Strain and Fermentation Conditions on Production of Cellulase by Trichoderma reesei. Biotechnol. Bioeng. 1989, 33, 650-656.

(9) Allen, A. L.; Mortensen, R. E. Production of Cellulases from Trichoderma reesei in Fed-Batch Fermentation from Soluble Carbon Sources. Biotechnol. Bioeng. 1981, 23, 2641-2645.
(10) J eong, J .; Park, H.; Hong, S.; Hah, Y. Aspects of Cellulase Induction by Sophorose in Trichoderma reesei QM 9414. Korean J . Microbiol. 1985, 23, 77-83.

(11) Mandels, M.; Parrish, F. W.; Reese, E. T. Sophorose as an Inducer of Cellulase in Trichoderma viride. J . Bacteriol . 1962 83, 400-408.

(12) Nisizawa, T.; Suzuki, H.; Nakayama, M.; Nisizawa, K. Inductive Formation of Cellulase by Sophorose in Trichoderma viride. J. Biochem. 1971, 70, 375-385.

(13) Sternberg, D.; Mandels, G. R. Induction of Cellulolytic Enzymes in Trichoderma reese by Sophorose. J . Bacteriol. 1979, 139, 761-769.

(14) Wu, J .; J u L.-K. Enhancing Enzymatic Saccharification of Waste Newsprint by Surfactant Addition. Biotechnol. Prog. 1998, 14, 649-652.

(15) Tangnu, S., K.; Blanch, H. W.; Wilke, C. R. Enhanced Production of Cellulase, Hemicellulase, and $\beta$-Glucosidase by Trichoderma reesei (Rut C-30). Biotechnol. Bi oeng. 1981, 23, 1837-1849.

(16) Ghose, T. K. Measurement of Cellulase Activities. Pure Appl. Chem. 1987, 59, 257-268.

(17) Brown, D. E.; Zainudeen, M. A. Growth Kinetics and Cellulase Biosynthesis in the Continuous Culture of Trichoderma viride Biotechnol. Bioeng. 1977, 19, 941-958.

(18) Brock, T. D.; Madigan, M. T.; Martinko, J . M.; Parker, J . Biology of Microorganisms, 7th ed.; Prentice Hall: Englewood Cliffs, NJ , 1994.

(19) Heijnen, J . J.; Roels, J . A. A Macroscopic Model Describing Yield and Maintenance Relationships in Aerobic Fermentation. Biotechnol. Bioeng. 1981, 23, 739-763.

(20) Ryu, D. D.; Andreotti, R.; Medeiros, J .; Mandels, M. Comparative Quantitative Physiology of High Cellulase Producing Strains of Trichoderma reesei. Enzyme Eng. 1980, 5, 33-40.

(21) Mandels, M.; Sternberg, D.; Andreotti, R. E. Growth and Cellulase Production by Trichoderma. In Symposium on Enzymatic Hydrolysis of Cellul ose (Aulanko, Finland, 1975); Bailey, M., Enari, T. M., Linko, M., Eds.; Finnish National Fund for Research and Development: Helsinki, 1975; pp 81109.

(22) Webb, C.; Fukuda, H.; Atkinson, B. The Production of Cellulases in a Spouted Bed Fermentor Using Cells Immobilized in Biomass Support Particles. Biotechnol. Bioeng. 1986, 28, 41-50.

(23) Turker, M.; Mavituna, F. Production of Cellulase by Freely Suspended and Immobilized Cells of Trichoderma reesei. Enzyme Microb. Technol. 1987, 9, 739-743.

(24) Steiner, W.; Doppelbauer, R.; Hayn, M.; Esterbauer, H. Production and Biochemical Characterization of Trichoderma reesei Cellulase. In Third European Congress on Biotechnology; Verlag Chemie: Weinheim, FRG, 1984; Vol. 2, pp 443449.

(25) J ewell, T. K. Computer Applications for Engineers; J ohn Wiley and Sons: New York, 1991.

(26) Demain, A. L. Regulatory Mechanisms and the I ndustrial Production of Microbial Metabolites. Lloydia 1968, 31, 395418.

(27) Miller, W. M.; Blanch, H. W.; Wilke, C. R. A Kinetic Analysis of Hybridoma Growth and Metabolism in Batch and Continuous Suspension Culture: Effect of Nutrient Concentration, Dilution Rate, and pH. Biotechnol. Bioeng. 1988, 32, 947-965.

(28) Mandels, M.; Reese, E. T. Induction of Cellulase in F ungi by Cellobiose. J . Bacteriol. 1960, 79, 816-826.

Accepted December 17, 1998.

BP980116N 